\title{
KEBIASAAN MAKAN YANG BERHUBUNGAN DENGAN KESEHATAN REPRODUKSI REMAJ A PUTRI DI KABUPATEN BOGOR
}

\author{
(Food Habits Related to Reproductive Health of Adolescent Girls \\ In Bogor Regency)
}

Yaktiworo Indriani ${ }^{1^{*}}$, Mellova $\mathrm{Amir}^{2}$, Iskandar Mirza ${ }^{3}$

\begin{abstract}
1* Alamat Korespondensi: Jurusan Sosial Ekonomi Pertanian, Fakultas Pertanian, Universitas Lampung, Bandar Lampung 35145. Telp/Faks: 0721-781821. Email: yakti_indriani@yahoo.com

2 Jurusan Farmasi, Institut Sains dan Teknologi Nasional, Jakarta

3 BPTP Propinsi Nangroe Aceh Darussalam
\end{abstract}

\begin{abstract}
This research aims was to study (1) food habits of adolescent girls; (2) the adolescent girls' efforts in taking care of and obtaining reproductive health; and (3) the relation between food habits, school level, parent's education level, and social economics level of family toward reproductive health of adolescent girls. This research was a cross-sectional study executed in class level of 1 and 2 of SMA Negeri I and SMP Negeri I of Dramaga District, in Bogor Regency in which 3 classes of each level so that totalize 12 classes. The number of subject was 169 adolescent girls. The data was collected by interviews and filling up questioners on May through J une 2008. The research result showed that food habit between adolescent girls of SMP and SMA was not different and both have not yet meet PUGS, especially still less in number consume of rice, animal products and plain water. Strive in overcoming the sigh appearance nearing and during menstruation which is often done by adolescent girls were by keeping it quiet, body massages, and lay down. Variables of eating frequency together with habitual of eating fruits, animal products, and sour or hot food during menstruation are significantly related with reproductive health of adolescent girls.
\end{abstract}

Key words: food habits, reproductive health, adolescent girl

\section{PENDAHULUAN}

Masa remaja merupakan waktu transisi antara anak-anak dan dewasa, periode perubahan fisik dan psikologis, serta masa pubertas. Dalam perkembangannya, remaja memerlukan informasi dan bimbingan yang benar dari sekolah, orang tua, lingkungan, teman, atau media (Path UNFPA, 2000 dan UNDP/UNFPA/ WHO, 2003). Pengetahuan remaja mengenai masalah kesehatan reproduksi di Indonesia selama tahun 2003 ternyata rendah. Guna mendapatkan informasi tentang kesehatan reproduksi, banyak remaja yang bergerilya mencari akses dan melakukan eksplorasi sendiri, baik melalui majalah, buku, dan film pornografi melalui internet (BKKBN, 2004).

Saat mulainya menstruasi, selain ditentukan oleh bawaan/keturunan juga dipengaruhi oleh status gizi pada awal kehidupan. Masa Pubertas menjadi periode utama perubahan kebiasaan dan perubahan gaya hidup, yang dipengaruhi oleh pengetahuan tentang makanan (gizi), ketersediaan makanan, pengaruh lingkungan dan lain lain. Distribusi makronutrien didominasi oleh lemak terutama asam lemak jenuh serta rendah karbohidrat kaya serat. Datangnya haid dapat terlambat pada remaja yang berstatus gizi kurang (Clavien et al, 1996).

Makan pagi secara teratur pada remaja dapat menurunkan resiko terhadap kelebihan berat badan dan merupakan kontributor penting terhadap pola hidup sehat dan status kesehatan (Yang et al, 2006). Pada kenyataanya kebiasaan makan pada remaja sering kurang ideal karena kesibukan, tekanan dari teman grup, alam bebas dan pencarian identitas diri, kadang-kadang menghilangkan makan sehingga hanya makan snack, atau mengonsumsi makanan siap saji, minuman ringan dan atau alkohol dalam jumlah yang berlebihan. 
Hingga kini belum banyak penelitian yang dilakukan yang berkaitan dengan kebiasaan dan kepercayaan makan yang berhubungan dengan kesehatan reproduksi pada remaja putri dan upaya yang dilakukan dalam menjaga dan memperoleh kesehatan reproduksinya serta faktor-faktor yang berhubungan dengan kesehatan reproduksi pada remaja putri.

Penelitian ini bertujuan untuk (1) mengetahui kebiasaan konsumsi makan dan kepercayaan terhadap makanan pada remaja putri; (2) mengetahui upaya remaja putri dalam menjaga dan memperoleh kesehatan reproduksi; serta (3) mengetahui hubungan antara kebiasaan makan, tingkat sekolah, pendidikan orang tua dan tingkat sosial ekonomi keluarga dengan kesehatan repro-duksi.

\section{METODE PENELITIAN}

\section{Desain, Tempat dan Waktu Penelitian}

Penelitian ini merupakan studi crosssectional yang dilaksanakan di SMA Negeri I dan SMP Negeri I Kecamatan Dramaga Kabupaten Bogor (masing-masing 3 klas sehingga total 12 klas). Tempat ini dipilih dengan pertimbangan lokasinya dekat dengan kampus IPB sehingga sesuai untuk melakukan penelitian ini yang merupakan studi pendahuluan dalam identifikasi kebiasaan dan kepercayaan makan, serta upaya remaja dalam menjaga kesehatan reproduksi. Pengambilan data penelitian dilakukan pada bulan Mei-Juni 2008.

\section{Sampel Penelitian}

SMAN I Dramaga Bogor baru memiliki masing-masing tingkat 3 klas, karena sekolah ini belum lama berdiri dan belum memiliki gedung sendiri, sehingga masih menumpang di gedung SMPN I Dramaga yang telah jauh lebih lama berdiri dan memiliki 6 klas untuk masingmasing tingkat. Oleh karena itu semua siswi klas 1 dan 2 SMA tersebut (6 kelas) dilibatkan sebagai sampel penelitian. Atas dasar ini maka untuk SMP dipilih pula masing-masing tingkat tiga klas dengan cluster random sampling. Adapun siswi klas 3 tidak dilibatkan dalam penelitian ini karena pada saat pengambilan data mereka telah selesai ujian. Remaja putri yang belum pernah mendapat haid atau mendapat haid pertamanya belum ada satu tahun dikeluarkan dari remaja penelitian.

Remaja yang terlibat dalam penelitian ini secara keseluruhan berjumlah 169 orang. Mereka terdiri dari 106 remaja SMA (kelas 1 sebanyak 65, dan kelas 2 sebanyak 41) dan 63 remaja SMP (kelas 1 sebanyak 26, dan kelas 2 sebanyak 37). Mereka berasal dari 121 anak SMA kelas 1 dan 2 dan 138 anak SMP kelas 1 dan kelas 2. Banyaknya remaja putri SMP yang gugur sebagai responden dikarenakan 44 anak (32\%) belum sampai satu tahun mendapatkan haid, dan 31 anak (22\%) sama sekali belum pernah mendapatkan haid.

\section{Pengumpulan dan Analisis Data}

Pengumpulan data menggunakan alat bantu kuesioner yang terdiri dari data identitas remaja putri dan keadaan umum keluarga, 6 pertanyaan yang berhubungan dengan kebiasaan makan, 20 pertanyaan yang berhubungan dengan kesehatan reproduksi dan 20 pertanyaan yang berkaitan dengan usahausaha untuk menjaga kesehatan reproduksi remaja putri serta 2 pertanyaan tentang kepercayaan yang berhubungan dengan kesehatan reproduksi.

Semua data penelitian dikumpulkan dan dianalisis menggunakan SPSS Version 15. Analisis deskriftif digunakan untuk menggambarkan kebiasaan makan dan kepercayaan terhadap makanan serta upaya remaja putri dalam menjaga dan memperoleh kesehatan reproduksi. Uji beda tidak berpasangan dengan uji-t digunakan untuk mengetahui perbedaan antara kebiasaan makan dan kepercayaan terhadap makanan antara remaja putri SMP dan SMA. Adapun analisis Pearson Correlation (dua arah pada level $\alpha=0.05$ dan 0.01) dan tabulasi silang digunakan untuk mengetahui hubungan antara kebiasaan, tingkat sekolah, pendidikan orang tua dan tingkat sosial ekonomi keluarga dengan kesehatan reproduksi.

\section{HASIL DAN PEMBAHASAN}

\section{Identitas dan Kesehatan Reproduksi Remaja Putri}

Hampir semua remaja $(95,3 \%)$ tinggal dengan orang tuanya, hanya $7(4,7 \%)$ yang tidak tinggal dengan orang tuanya (1 SMP dan 6 SMA). Rumah yang mereka tempati sebagian besar adalah milik sendiri (74,6\%). Sebagian besar ayah responden berpendidikan tamat SMA atau yang lebih tinggi $(56,1 \%)$ dan merupakan pegawai swasta $(74 \%)$ dengan gaji di atas satu juta rupiah (54.4\%). Adapun sebagian besar ibu responden pendidikannya hanya SD atau SMP (60.9\%) dan tidak bekerja (78.7\%). 
Sebagian besar $(72 \%)$ remaja dalam satu tahun terakhir pernah mengalami 1-3 macam penyakit, sedangkan yang menyatakan tidak pernah sakit sebanyak 31 remaja (19\%). Sebagian besar $(54 \%)$ remaja melakukan olahraga hanya sekali per minggu, sedangkan yang melakukan olahraga tiga kali atau lebih per minggu hanya sebesar $22 \%$. Jenis olahraga yang paling banyak dilakukan adalah lari (joging), senam, dan badminton. Frekuensi dalam melakukan aktivitas olahraga per minggu oleh remaja SMA lebih jarang dan lebih sedikit waktunya dibandingkan dengan remaja SMP.

Data kesehatan reproduksi remaja putri dalam penelitian ini difokuskan pada hal-hal yang terkait dengan haidnya, sumber pengetahuan tentang kesehatan reproduksi, keberadaan pacar atau teman dekat, rencana pendidikan, rencana usia menikah dan hamil serta memiliki anak pertama, serta jenis dan frekuensi olahraga yang sering dilakukan. Pada Tabel 1 dapat dilihat beberapa nilai rerata indikator yang terkait dengan kesehatan reproduksi pada remaja putri menurut tingkat sekolah.

Umur remaja pertama kali mendapatkan haid bervariasi antara 9-15 tahun dengan rerata 12.79 tahun; dan rerata lamanya haid adalah 6.42 hari. Umur pertama kali mendapatkan haid ternyata semakin turun, di mana rerata pada remaja SMA $13,12 \pm 1,1$ tahun berbeda sangat nyata dengan remaja SMP $12.25 \pm 0.85$ tahun $(\alpha=0.01)$. Adapun usia menikah (23.62 tahun) dan memiliki anak (25.32 tahun) bagi remaja SMP dan SMA tidak berbeda nyata. Jenis penyakit yang paling sering dikeluhkan menjelang haid adalah sakit perut (42\%), diikuti oleh pegal-pegal (40\%), dan emosi tinggi (39\%). Adapun keluhan pada saat haid yang paling sering adalah nyeri perut bagian bawah (40\%), diikuti oleh emosi tinggi (33\%), dan pegal-pegal (32\%). Hanya ada satu remaja (klas 2 SMP) yang menyatakan sering pingsan pada saat mendapat haid.

Hampir semua (96\%) remaja menyatakan punya sahabat yaitu beberapa wanita (66\%) atau satu orang wanita $(34 \%)$ dan sebanyak 62 remaja (63\%) melaporkan sudah punya pacar. Pengetahuan tentang kesehatan reproduksi yang dimiliki remaja sebagian besar sumber pertamanya berasal dari orang tuanya $(70 \%)$, buku $(6,5 \%)$, dan guru (5,9\%). Adapun sumber ke dua tentang pengetahuan kesehatan reproduksi mereka peroleh dari teman $(24,3 \%)$, buku (17,2\%), dan Televisi (14,2\%). Hasil ini berbeda dengan penelitian Qomariyah (2002) yang menyatakan bahwa sumber utama pengetahuan kesehatan reproduksi majalah $(38,1 \%)$ dan guru $(36 \%)$ untuk SMA sedangkan untuk SMP orangtua.

\section{Kebiasaan Makan Remaja Putri}

Ditinjau dari frekuensi makan per hari, cukup banyak remaja yang makan kurang dari tiga kali per hari, yakni sebanyak $45,85 \%$. Menurut Pedoman Umum Gizi Seimbang (PUGS) untuk memenuhi angka kecukupan gizi (AKG), bagi remaja usia 13-19 tahun sebaiknya mengkonsumsi nasi atau penggantinya 3-4 piring; lauk hewani 3-4 potong; lauk nabati 2-4 potong; sayuran 11/2-2 mangkuk; dan buahbuahan 2-3 potong serta air putih 8 gelas per hari Soekirman dan Atmawikarta (2004). Kebiasaan makan remaja putri menunjukkan belum memenuhi PUGS, hampir setengah dari total remaja (remaja SMP dan SMA) tidak makan dengan frekuensi makan 3 kali per hari. Konsumsi rata-rata kelompok makanan nasi, lauk hewani dan air putih para remaja putri masih di bawah PUGS. Adapun konsumsi lauk nabati, sayuran dan buah-buahan telah memenuhi PUGS. Kebiasaan makan menurut golongan pangan pada remaja SMP dan SMA disajikan pada Tabel 2.

Tabel 1. Nilai Rerata Beberapa Indikator yang Terkait dengan Kesehatan Reproduksi pada Remaja Putri Menurut Tingkat Sekolah

\begin{tabular}{|c|c|c|c|c|}
\hline \multirow[t]{2}{*}{ Indikator } & \multicolumn{2}{|c|}{ SMP $(n=63)$} & \multicolumn{2}{|c|}{ SMA $(n=106)$} \\
\hline & Rerata & SD & Rerata & SD \\
\hline Umur pertama kali haid (tahun) ${ }^{* *}$ & 12.25 & 0.85 & 13.12 & 1.10 \\
\hline Lamanya haid (hari) & 6.52 & 1.66 & 6.36 & 1.07 \\
\hline Rencana usia menikah (tahun) & 23.78 & 2.29 & 23.52 & 1.99 \\
\hline Rencana usia memiliki anak (tahun) & 25.32 & 2.61 & 25.33 & 2.59 \\
\hline Frekuensi olahraga (kali/minggu) & 1.98 & 1.38 & 1.66 & 1.02 \\
\hline Lama olahraga (menit/minggu) & 109.21 & 151.83 & 43.85 & 41.35 \\
\hline
\end{tabular}


Tabel 2. Sebaran Kebiasaan Makan Berbagai Kelompok Pangan pada Remaja Putri Menurut Porsi Makan Per Hari (\%)

\begin{tabular}{|c|c|c|c|c|}
\hline Jenis makanan & $\begin{array}{l}\text { Porsi yang } \\
\text { dianjurkan PUGS }\end{array}$ & $\begin{array}{l}\text { Porsi yang } \\
\text { dikonsumsi }\end{array}$ & $\begin{array}{l}\text { SMP } \\
(\%)\end{array}$ & $\begin{array}{l}\text { SMA } \\
(\%)\end{array}$ \\
\hline \multirow[t]{3}{*}{ Nasi } & 3-4 piring & $0-1$ & 11.1 & 5.7 \\
\hline & & $1.5-2.5$ & 42.9 & 54.3 \\
\hline & & $\geq 3.0$ & 46.0 & 40.0 \\
\hline \multirow[t]{3}{*}{ Lauk Hewani } & $3-4$ potong & $\leq 1.0$ & 14.3 & 14.4 \\
\hline & & $1.5-2.5$ & 42.8 & 43.3 \\
\hline & & $\geq 3.0$ & 42.9 & 42.3 \\
\hline \multirow[t]{3}{*}{ Lauk Nabati } & $2-4$ potong & $\leq 1.0$ & 14.5 & 14.4 \\
\hline & & $>1.0-2.0$ & 25.8 & 31.8 \\
\hline & & $\geq 2.0$ & 59.7 & 53.8 \\
\hline \multirow[t]{3}{*}{ Sayuran } & $1,5-2$ mangkuk & $<1.5$ & 44.4 & 42.3 \\
\hline & & $\geq 1.5-2.0$ & 31.2 & 34.6 \\
\hline & & $>2.0$ & 23.8 & 23.8 \\
\hline \multirow[t]{3}{*}{ Buah-buahan } & $2-3$ potong & $<2.0$ & 36.5 & 35 \\
\hline & & $\geq 2.0-3.0$ & 42.9 & 48.5 \\
\hline & & $>3.0$ & 20.6 & 16.5 \\
\hline \multirow[t]{3}{*}{ Susu } & gelas & $<1.0$ & 31.7 & 15.2 \\
\hline & & 1.0 & 22.3 & 35.4 \\
\hline & & $\geq 2$ & 46 & 35.4 \\
\hline \multirow[t]{3}{*}{ Air Putih ${ }^{* *}$} & 8 gelas & $<4$ & 24.2 & 12.6 \\
\hline & & $4-7.5$ & 50.0 & 51.5 \\
\hline & & $\geq 8$ & 25.8 & 35.9 \\
\hline
\end{tabular}

* Pedoman Umum Gizi Seimbang

** Berbeda nyata antara remaja putri SMP dengan SMA $(\alpha=0.05)$

Pada Tabel 2 dapat dilihat bahwa konsumsi nasi pada sebagian besar remaja baik SMP (54\%) maupun SMA (60\%) tidak sampai tiga kali per hari. Bahkan ada remaja yang konsumsi nasinya kurang dari 1 piring per hari (SMP 11.1\% dan SMA (5.7\%). Rata-rata konsumsi nasi pada remaja SMP dan SMA tidak berbeda nyata yaitu 2,4 dan 2,5 piring per hari. Makanan pengganti nasi yang paling sering dikonsumsi oleh para remaja adalah bakso/mi, umbi-umbian, dan bubur ayam.

Ukuran atau porsi konsumsi lauk hewani pada remaja SMP dan SMA juga tidak jauh berbeda, di mana ukuran 2 potong per hari merupakan takaran tertinggi baik pada remaja SMP maupun SMA. Pada sebagian remaja juga dijumpai yang mengkonsumsi lauk hewani kurang dari 1 potong per hari yakni 4,8\% pada SMP dan 1,0\% pada SMA. Rata-rata konsumsi lauk hewani pada remaja SMP dan SMA adalah 2,47 dan 2,48 potong per hari serta tidak ada perbedaan yang nyata antar keduanya. Lauk hewani yang paling sering dimakan remaja berturut-turut adalah ayam (SMP 69,5\%; SMA 53,1\%), ikan (SMP 61,0\%; SMA 65,6\%), telur (SMP 55,9\%; SMA 68,8\%) dan daging (SMP 33,9\%; SMA 16,7\%). Adapun untuk lauk nabati berturut-turut adalah tempe (SMP/SMA 92,5\%), tahu (SMP 92,5\%; SMA 77,4\%), dan bakwan (SMP 18,9\%; SMA 1,8\%).
Tidak jauh berbeda dengan konsumsi nasi dan lauk hewani, rata-rata konsumsi lauk nabati, sayuran dan buah-buahan pada remaja SMP dan SMA juga tidak berbeda nyata, yakni 2,78 potong; 1,66 mangkuk; dan 2,30 potong per hari. Adapun konsumsi air putih per hari pada remaja SMP rata-rata sebesar 5,48 gelas berbeda nyata dengan remaja SMA sebesar 6,83 gelas. Meskipun konsumsi susu bagi remaja tidak dianjurkan dalam PUGS, namun remaja dalam penelitian ini mengkonsumsi susu rata-rata 1,44 gelas per hari. Remaja SMP dan SMA yang mengkonsumsi susu bubuk sebanyak 58,7 dan $48,1 \%$ sedangkan susu cair 81,0 dan $63,2 \%$. Sayuran yang paling sering dikonsumsi remaja adalah bayam, sup, dan kangkung masing-masing $30,4 \% ; 23,2 \%$ dan $17,9 \%$ pada remaja SMP, dan $57,8 \%, 42,2 \%$, dan 40,0\% pada remaja SMA.

Kebiasaan konsumsi jajanan di kalangan remaja SMP mencapai $92,1 \%$ dan SMA $77,4 \%$. Pengeluaran rata-rata per bulan untuk jajan baik di sekolah maupun di luar sekolah pada remaja putri SMP sebesar Rp31.967,21 berbeda nyata dengan SMA sebesar Rp34.994,62. Meskipun pengeluaran untuk jajannya lebih kecil, namun frekuensi jajan remaja putri SMP nyata lebih sering dibandingkan dengan remaja SMA. Remaja SMP yang sering jajan di sekolah mencapai $85,7 \%$ dan di luar sekolah mencapai 
$71,4 \%$, sedangkan untuk remaja SMA mencapai $87,9 \%$ dan $47,7 \%$. Untuk jajanan camilan, yang paling diminati oleh semua remaja berturutturut adalah adalah goreng-gorengan (tahu, tempe dan bakwan), cimol (aci goreng), chiki, dan buah-buahan potong.

\section{Upaya Remaja Putri dalam Menjaga dan Memperoleh Kesehatan Reproduksi}

Upaya yang dilakukan oleh remaja putri dalam mengatasi keluhan pada saat sebelum haid dengan minum obat+jamu adalah 34.9\% pada SMP, dan $28.7 \%$ pada SMA. Adapun pada saat haid remaja yang minum obat+jamu sebanyak $36.5 \%$ pada SMP, dan $41.7 \%$ pada SMA. Upaya yang paling banyak dilakukan oleh remaja putri SMP dan SMA untuk mengatasi keluhan pada saat sebelum haid adalah tiduran (SMP 28.6\%; SMA 40.6\%) dan membiarkan saja (SMP 33.3\%; SMA 38.7\%), dipijit (SMP 22.2\%; SMA 31.1\%), diikuti dengan mengkonsumsi obat dan minum jamu. Upaya yang banyak dilakukan oleh remaja putri pada saat haid untuk mengatasi keluhannya adalah tidur-tiduran (SMP 33.3\%; SMA 48.1\%) atau menbiarkannya saja (SMP 35\% anak; SMA 37.8\%). Hasil selengkapnya dapat dilihat pada Tabel 3 .
Remaja yang melakukan upaya khusus untuk menjaga kebersihan alat kelamin pada saat haid maupun tidak haid hanya sedikit. Walaupun masih relatif sedikit, upaya dilakukan oleh remaja SMA sedikit lebih banyak (saat haid dan tidak haid 34\%), dibandingkan dengan SMP (saat haid 19\%, tidak haid $25.4 \%$ ).

Adapun upaya yang dilakukan remaja putri SMA untuk merawat bagian lain adalah merawat rambut dan wajah yang lebih pada penampilan. Pada Tabel 4 dapat dilihat ada tidaknya upaya remaja dalam melakukan perawatan beberapa bagian khusus tubuhnya. Kebiasaan dan upaya yang dilakukan dalam merawat bagian khusus pada remaja putri SMP dan SMA lebih banyak merawat rambut $(90.0 \%$; $84.9 \%)$ dan wajah $(71.4 \%$; $72.6 \%)$, diikuti oleh mata $(42.9 \% ; 31.1 \%)$, tangan, badan, rahim dan gigi.

Upaya yang dilakukan remaja putri SMP dan SMA untuk mengatasi keluhannya sebelum dan saat haid cukup bervariasi antara lain dengan minum jamu atau obat hingga pergi ke dokter oleh yang dilakukan oleh 5 remaja saja. Namun demikian keluhan yang muncul belum sampai pada tahap yang akut, sehingga yang paling banyak dilakukan adalah dengan membiarkannya saja, pijit atau cukup dengan tiduran.

Tabel 3. Usaha yang Dilakukan oleh Remaja Putri pada Sebelum dan Saat Haid

\begin{tabular}{|c|c|c|c|c|c|}
\hline \multirow{2}{*}{\multicolumn{2}{|c|}{ Upaya }} & \multicolumn{2}{|c|}{ Sebelum Haid (J umlah) } & \multicolumn{2}{|c|}{ Saat Haid (J umlah) } \\
\hline & & SMP $(n=63)$ & SMA $(n=106)$ & SMP $(n=63)$ & SMA $(n=106)$ \\
\hline \multirow[t]{3}{*}{ Konsumsi: } & Jamu & 9 & 6 & 8 & 6 \\
\hline & Kiranti & 4 & 3 & 6 & 3 \\
\hline & Ngemil & 2 & 0 & 2 & 0 \\
\hline \multirow[t]{2}{*}{ Medis } & Obat & 9 & 21 & 9 & 35 \\
\hline & ke dokter & 1 & 2 & 2 & 3 \\
\hline \multicolumn{2}{|c|}{ Non medis: Pijit } & 14 & 33 & 11 & 22 \\
\hline & Olahraga & 3 & 1 & 1 & 0 \\
\hline \multicolumn{2}{|c|}{ Istirahat dan Tiduran } & 30 & 44 & 29 & 59 \\
\hline \multicolumn{2}{|c|}{ Dibiarkan/Tidak ada upaya } & 21 & 41 & 22 & 40 \\
\hline
\end{tabular}

Tabel 4. Kebiasaan dan Upaya yang Dilakukan Remaja untuk Merawat Bagian Khusus

\begin{tabular}{lcccc}
\hline \multirow{2}{*}{ Bagian Tubuh } & \multicolumn{2}{c}{ SMP $(\mathbf{n = 6 3 )}$} & \multicolumn{2}{c}{ SMA (n=106) } \\
\cline { 2 - 5 } & Ya & Tidak & Ya & Tidak \\
\hline Payudara & 7 & 56 & 6 & 100 \\
Rahim & 10 & 53 & 5 & 101 \\
Rambut & 57 & 6 & 90 & 16 \\
Wajah & 45 & 18 & 77 & 29 \\
Mata & 27 & 36 & 33 & 73 \\
Tangan dan badan & 11 & 52 & 15 & 91 \\
Gigi & 6 & 57 & 6 & 100 \\
\hline
\end{tabular}


Remaja SMP lebih banyak minum jamu dibandingkan dengan SMA Upaya yang dilakukan untuk merawat bagian khusus wanita lebih banyak pada perawatan rambut dan wajah yang terlihat lebih pada penampilan fisik dari pada melakukan upaya khusus dalam menjaga kebersihan alat kelamin pada saat sebelum dan saat haid. Hal ini mungkin disebabkan faktor budaya setempat yang lebih mementingkan penampilan atau mungkin juga pengetahuan kesehatannya masih kurang.

\section{Hubungan antara Kebiasaan, Tingkat Sekolah, Pendidikan Orang Tua dan Tingkat Sosial Ekonomi Keluarga dengan Kesehatan Reproduksi pada Remaja Putri}

Frekuensi makan makanan utama berhubungan positif dengan banyaknya haid yang normal, remaja yang makan tiga kali sehari akan mengalami haid yang lebih normal dibandingkan dengan yang makan kurang dari 3 kali per hari. Kebiasaan makan buah berhubungan negatif dengan jarak antar haid normal namun berhubungan positif dengan lamanya haid normal. Kebiasaan makan lauk hewani berhubungan positif dengan lamanya haid normal, namun berhubungan negatif dengan nyeri saat darah keluar dan pusing saat haid. Pada Tabel 5 dapat dilihat korelasi antara berbagai kebiasaan makan dan tingkat sekolah terhadap berbagai indikator kesehatan reproduksi pada remaja putri secara lengkap.
Berdasarkan analisis statistik didapatkan hasil bahwa variabel-variabel yang berhubungan secara nyata dengan kesehatan reproduksi pada remaja putri adalah frekuensi makan makanan utama; kebiasan makan buah, lauk hewani, jajan di sekolah dan di luar sekolah; kebiasaan mengkonsumsi makanan pedas/asam saat haid serta tingkat sekolah. Adapun kebiasaan makan nasi, lauk nabati, sayuran, susu, dan air putih, serta kebiasaan mengonsumsi makanan pedas/asam pada saat menjelang haid tidak berhubungan dengan kesehatan reproduksi. Demikian pula variabel pendidikan orang tua dan tingkat sosial ekonomi keluarga ternyata tidak berhubungan dengan kesehatan reproduksi remaja putri.

Kebiasaan makan buah pada remaja putri nyata berhubungan negatif dengan jarak antar haid yang normal $(r=-0,181)$ dan berhubungan positif sangat nyata dengan lamanya haid $(r=0,227)$. Hal ini mengisyaratkan bahwa semakin banyak remaja putri mengonsumsi buah, maka jarak antar haidnya jadi kurang normal, yaitu kurang dari 28 hari atau lebih dari 35 hari (The National Women's Health Information Center, 2002) dan waktu haidnya akan semakin lama. Namun, dari hasil tabulasi silang dapat dilihat bahwa hal tersebut terjadi pada remaja yang konsumsi buahnya lebih tinggi dari 3 porsi per hari, sedangkan yang konsumsinya kurang atau sama dengan 3 porsi

Tabel 5. Nilai Korelasi antara Kebiasaan Makan dan Tingkat Sekolah terhadap Kesehatan Reproduksi Remaja Putri

\begin{tabular}{llc}
\hline \multicolumn{1}{c}{ Variabel } & Indikator Kesehatan reproduksi & $\begin{array}{c}\text { Korelasi } \\
\text { Pearson }\end{array}$ \\
\hline Frekuensi makan makanan utama & Banyaknya haid normal & $0.168^{*}$ \\
Kebiasaan makan buah & Jarak antar haid normal & $-0.181^{*}$ \\
& Lamanya haid & $0.227^{* *}$ \\
Kebiasaan makan lauk hewani & Lamanya haid & $0.172^{*}$ \\
& Nyeri saat darah keluar & $-0.181^{*}$ \\
Kebiasaan makan makanan jajanan & Pusing saat haid & $-0.176^{*}$ \\
Kebiasaan jajan di sekolah & Lemas saat haid & $0.187^{*}$ \\
& Jarak antar haid normal & $0.303^{* *}$ \\
Kebiasaan jajan di luar sekolah & Mual-mual saat haid & $-0.222^{* *}$ \\
& Pusing saat haid & $-0.212^{* *}$ \\
Kebiasaan mengkonsumsi makanan pedas/asam & $-0.169^{*}$ \\
saat haid & Lemas saad haid & $-0.174^{*}$ \\
Tingkat Sekolah & Pegal-pegal saat haid & $-0.218^{* *}$ \\
& Emosi tinggi saat haid & $0.240^{* *}$ \\
\hline
\end{tabular}

**Korelasi sangat nyata pada level 0.01.

*Korelasi nyata pada level 0.05 . 
per hari jarak antar haidnya lebih banyak yang normal. Waktu mendapatkan haid yang normal adalah 2-7 hari, dari hasil analisis tabulasi silang dapat dilihat bahwa meskipun semakin banyak mengkonsumsi buah akan semakin lama waktu haidnya, pada yang mengkonsumsi buah antara 0-3 porsi per hari (88\%) waktu haidnya masih dalam selang normal yaitu 2-7 hari. Proporsi remaja yang waktu haidnya 7 hari dimiliki oleh yang konsumsi buahnya 3 kali perhari. Mereka yang konsumsi buah kurang dari 3 kali, cenderung masa haidnya banyak yang lebih pendek dari 7 hari.

Kebiasaan makan lauk hewani berhubungan nyata positif dengan lamanya haid normal $(r=0.172)$; serta berhubungan negatif dengan rasa nyeri saat darah haid keluar $(r=-$ $0.181)$ dan rasa pusing saat haid $(r=-0.176)$. Hal ini berarti remaja yang banyak mengonsumsi lauk hewani akan mengalami masa haid yang lebih normal dan kurang merasakan nyeri maupun pusing saat darah haid keluar. Munculnya rasa nyeri kemungkinan diakibatkan oleh ketidakseimbangan hormon, sedangkan rasa pusing bisa jadi diakibatkan oleh rendahnya zat besi, yang penting bagi pembentukan hemoglobin dalam tubuh, yang dipicu oleh keluarnya darah saat haid. Remaja yang mengkonsumsi pangan hewani akan mendapatkan protein dan zat besi dalam jumlah yang cukup untuk pembentukan hemoglobin sehingga mereka tidak mengalami pusing, serta kemungkinan juga berpengaruh pada tercukupinya keseimbangan hormon.

Kebiasaan jajan di sekolah nyata berhubungan positif dengan jarak antar haid yang normal ( $r=0.303)$; serta berhubungan negatif dengan mual-mual saat haid $(r=-0.222)$. Adapun kebiasaan jajan di luar sekolah sangat nyata mengurangi pusing saat haid $(r=-0.212)$ dan emosi yang tinggi saat haid $(r=-0.218)$, serta dapat nyata mengurangi lemas saat haid $(r=-0.169)$ dan pegal-pegal saat haid $(r=-$ 0.174 ). Tingkat sekolah juga berhubungan nyata dengan darah haid sangat banyak $(r=0.203)$ dan emosi tinggi saat haid $(r=0.170)$, di mana pada remaja SMA lebih sering mengalami darah haid sangat banyak dan memiliki emosi tinggi saat haid.

Tingginya kebiasaan makan jajanan di sekolah maupun luar sekolah pada remaja putri ini sesuai dengan yang disarankan oleh Lew and Barlow (2005) dan Gayle et al. (2007). Hal ini dikarenakan saat ini banyak remaja 138 yang tidak sarapan pagi atau melewatkan makan siang, sehingga jika tidak ditambah dengan snack asupan gizinya akan kurang.

Lew and Barlow (2005) dan Gayle, et al. (2007) menyatakan bahwa pola hidup bagi remaja sekarang, makanan ringan/snack sudah menjadi bagian yang penting dari intik makanan setiap hari. Snack dilaporkan menyumbang seperempat dari intik energi dalam sehari tetapi umumnya tinggi lemak dan gula tetapi rendah dalam zat besi, kalsium, vitamin A, C dan folat. Meskipun kebiasaan makan ini meningkatkan resiko berbahaya bagi kesehatan manusia sebagai hasil dari intik bahan tambahan makanan, antioksidan, pemanis, pengawet dan dispekulasi tidak hanya mempengaruhi pola hidup kini tetapi juga merangsang gynecologic disorders seperti dysmenorrhea dan menstruasi yang tidak teratur; namun data studi menyarankan agar remaja sering makan snack terutama pada saat waktu senggang.

\section{KESIMPULAN}

Rata-rata konsumsi makanan per hari pada remaja putri SMP dan SMA menurut kelompok pangan berturut-turut adalah nasi atau penggantinya 2.45 piring, lauk hewani 2.48 potong, lauk nabati 2.79 potong, sayuran 1.66 mangkuk, buah-buahan 2.30 potong, dan air putih 6.32 gelas. Kebiasaan makan remaja putri tersebut belum sepenuhnya sesuai dengan PUGS terutama masih kurang dalam jumlah konsumsi nasi, lauk hewani dan air putih, sedangkan konsumsi lauk nabati, buah dan sayuran sudah memenuhi PUGS. Kebiasaan makan antara remaja putri SMP dan SMA tidak berbeda nyata, kecuali remaja SMA nyata lebih tinggi dalam mengkonsumsi air putih.

Upaya dalam mengatasi munculnya keluhan menjelang dan saat haid yang sering dilakukan oleh remaja putri adalah dengan mendiamkannya, pijit, dan tiduran, selain itu beberapa remaja juga minum jamu atau obat untuk mengatasi rasa sakit.

Variabel-variabel yang berhubungan nyata dengan kesehatan reproduksi pada remaja putri adalah (a) frekuensi makan makanan utama; (b) kebiasaan makan buah, lauk hewani, jajan di sekolah dan di luar sekolah; kebiasaan mengkonsumsi makanan pedas/asam saat haid, serta (c) tingkat sekolah. Frekuensi 
makan makanan utama berhubungan positif dengan banyaknya haid yang normal.

\section{DAFTAR PUSTAKA}

[BKKBN] Badan Koordinasi Keluarga Berencana. 2004. Kualitas kesehatan remaja tahun 2003. Rubrik Kesehatan Reproduksi Remaja. http://www.bkkbn.go.id [3 Oktober 2008].

Clavien H, Theintz G, Rizzoli R, Bonjour JP. 1996. Does puberty alter dietary habits in adolescents living in a western society?. Journal of Adolescent Health, 19 (1), 68-75.

Gayle S, Abbie MF, Kylie B, Anthony W, David C. 2007. Snacking behaviours of adolescents and their association with skipping meals. Int J Behav Nutr Phys Act, 4: 36.

Lew K, P J Barlow. 2005. Dietary practices of adolescents in Singapore and Malaysia. Singapore Med J, 46 (6), 282.
Path UNFPA: Kesehatan Reproduksi Remaja: Membangun Perubahan yang Bermakna; Out Look 16; 2000.

Qomariyah SN 2002. Ringkasan penelitian pengetahuan tentang kesehatan reproduksi di kalangan murid SMP. http://situs.kesrepro.info/ index.htm. [25 April 2008].

Soekirman \& Atmawikarta A. 2004. Pedoman umum gizi seimbang (PUGS). www.gizinet.com [7 Januari 2007].

The National Women's Health Information Center. 2002. What is a Typical Menstrual Period Like? U.S. Department of Health and Human Services.

UNDP/UNFPA/WHO. 2003. Preparing for Adult: Adolescent Sexual and Reproductive Health; Progress in Reproductive Health Research.

Yang RJ, Edward KW, Yeu S, Mei YC. 2006. Irregular breakfast eating and health status among adolescents in Taiwan. BMC Public Health, 6, 295. 